\title{
$\mathrm{Ca}^{2+}$ Signaling in B Cells
}

\author{
Taras Lyubchenko \\ Department of Medicine, University of Colorado Denver School of Medicine \\ E-mail: taras.lyubchenko@ucdenver.edu
}

Received September 4, 2010; Revised October 20, 2010, Accepted October 31, 2010; Published November 16, 2010

An increase in intracellular $\mathrm{Ca}^{2+}$ concentration is one of the major initial steps in B-cell activation that occurs within minutes after antigen receptor (BCR) engagement. In recent years, significant advances have been made in characterizing molecular mechanisms of $\mathrm{Ca}^{2+}$ signaling in lymphocytes, although the majority of work was done on $\mathrm{T}$ cells. This mini-review discusses several underexplored areas of $\mathrm{Ca}^{2+}$ signaling in $\mathrm{B}$ cells: (1) $\mathrm{Ca}^{2+}$ signaling in immune synapse and multifaceted $\mathrm{Ca}^{2+}$ responses within a single cell, (2) source of $\mathrm{Ca}^{2+}$ involved in $\mathrm{Ca}^{2+}$-dependent protein phosphorylation events and the role of store-operated influx, (3) role of $\mathrm{BCR}$ coreceptors in $\mathrm{Ca}^{2+}$ signaling, and (4) $\mathrm{Ca}^{2+}$ signaling and maintenance of $\mathrm{B}$-cell tolerance and clinical significance of $\mathrm{Ca}^{2+}$ signaling alterations.

KEYWORDS: calcium signaling, B lymphocytes, B cell receptor, CD21, immune synapse, anergy, autoimmunity

The role of intracellular $\mathrm{Ca}^{2+}$ increases in B-lymphocyte activation induced by antigen receptor (BCR) ligation has been actively studied since the late 1970s. It is well established that in B cells, similar to other nonexcitable cells types, $\mathrm{Ca}^{2+}$ serves as a universal second messenger required for signal transduction $[1,2,3,4]$ and that intracellular stores as well as extracellular environment serve as sources of $\mathrm{Ca}^{2+}[5]$. Dynamic characteristics of BCR-induced $\mathrm{Ca}^{2+}$ responses (amplitude, time course, etc.) are important in the activation of specific transcription factors that regulate immune functions, cell differentiation, proliferation, or cell death[6,7,8]. The majority of work on $\mathrm{Ca}^{2+}$ signaling in immune cells has been focused on $\mathrm{T}$ lymphocytes and these studies have proven that $\mathrm{Ca}^{2+}$ release-activated channels (CRAC) comprise the major influx mechanism and that the transmembrane proteins STIM and Orai play key roles in this process[9,10,11]. An identical/very similar CRAC influx mechanism highly selective for $\mathrm{Ca}^{2+}$ over other cations (which is a characteristic feature of CRAC[12]) and regulated by STIM was also described in primary murine B lymphocytes[13]. STIM1 and STIM2 are novel transmembrane $\mathrm{Ca}^{2+}$ regulatory proteins recently identified and implicated as playing a key role in CRAC-mediated $\mathrm{Ca}^{2+}$ influx in lymphocytes[10,14]. In contrast to $\mathrm{T}$ cells, the role of STIM1 in antigen receptor-mediated $\mathrm{Ca}^{2+}$ signaling in primary B cells and its subcellular localization has not been studied in great detail. Although the presence of STIM1 in B cells was suggested early on[15,16], most of the current knowledge about STIM/Orai-mediated influx comes from non-B-cell studies, including $\mathrm{T}$ cells, insect cells, and fibroblasts. This mechanism is believed to be evolutionarily conserved and to include B lymphocytes, whereby STIM directly monitors the $\mathrm{Ca}^{2+}$ concentration in the endoplasmic reticulum (ER) lumen. These possibilities are discussed in an excellent review[17], along with potential new roles for distinct $\mathrm{Ca}^{2+}$ mobilization profiles in individual primary $\mathrm{B}$-cell subsets and nuclear translocation of transcription 
factors as downstream targets of $\mathrm{Ca}^{2+}$ mobilization. Recent findings of mutant analysis based on structure-function experiments in chicken DT40 cells suggested that constitutive dynamic movement of STIM1 in the ER subcompartments is obligatory for subsequent depletion-dependent redistribution of STIM1 into puncta underneath the plasma membrane and activation of store-operated channels (SOC)[18]. It has also been demonstrated that the coupling of $\mathrm{Ca}^{2+}$ store release to $\mathrm{I}_{\text {crac }}$ channel activation in DT40 chicken B cells requires tonic activity of Lyn and Syk kinases, and that the action of kinases on $\mathrm{I}_{\text {crac }}$ activation does not arise from control of the expression level of STIM1 and Orail proteins[19]. Smyth et al.[20] examined $\mathrm{Ca}^{2+}$-store-dependent reversal of STIM1 localization in HEK293 cells and demonstrated that SOC $\mathrm{Ca}^{2+}$ entry is tightly coupled to formation of STIM1 puncta, and both SOC and puncta formation involve a dynamic and reversible signaling complex. Expression of STIM1 and STIM2 has been reported in CD3+/CD4+-, CD3+/CD8+-, and CD19+ murine lymphocytes[21]. However, recent reports suggest that, unlike STIM1, STIM2 has a smaller role in T-lymphocyte signaling[22]. Given a considerable level of similarities between BCR and TCR signaling mechanisms, STIM2 may not play a major role in B cells as well.

However, CRAC is not the only mechanism of $\mathrm{Ca}^{2+}$ delivery in lymphocytes. Other mechanisms of $\mathrm{Ca}^{2+}$ homeostasis regulation include well-characterized sarco-endoplasmic reticulum $\mathrm{Ca}^{2+}$ ATPases (SERCA)[23] and plasma membrane $\mathrm{Ca}^{2+}$ ATPases (PMCA)[24] that transport $\mathrm{Ca}^{2+}$ into intracellular stores or outside the cell, respectively; plasma membrane $\mathrm{Na}^{+} / \mathrm{Ca}^{2+}$ exchange pump[25] and mitochondrial $\mathrm{Ca}^{2+}$ transport systems[26]; passive $\mathrm{Ca}^{2+}$ diffusion routes through inositoltriphosphate from ER stores into the cytosol[27] and simply through the plasma membrane[28]; membrane potential-modulated channels, such as voltage-gated and $\mathrm{Ca}^{2+}$-activated $\mathrm{K}^{+}$channels[29,30] and transient receptor potential melastatinrelated (TRPM) family of channels that depolarize the membrane[31,32]; transient receptor potential vanilloid receptors (TRPV)[33] and nonselective $\mathrm{Ca}^{2+}$-permeable transient receptor potential channels (TRPC)[34].

One important feature of the CRAC-mediated mechanism is that intracellular $\mathrm{Ca}^{2+}$ concentration increases as a result of influx from extracellular media through SOC triggered by a release of relatively small quantities of $\mathrm{Ca}^{2+}$ from intracellular stores (Fig. 1). Regulatory mechanisms connecting store depletion with the opening of transmembrane channels have been studied and IP3 has been implicated in the regulation of membrane channels through conformational changes induced by depletion of intracellular $\mathrm{Ca}^{2+}$ stores[35]. More recent studies revealed key molecular details of this process in $\mathrm{T}$ lymphocytes and established the role of the above-mentioned STIM1/2 and Orai proteins as molecular sensors for intracellular $\mathrm{Ca}^{2+}$ store depletion and membrane pore unit, respectively. These mechanisms are discussed in great detail in two excellent reviews[36,37] and are beyond the scope of this manuscript.

A number of signaling molecules are involved in the generation of BCR-triggered $\mathrm{Ca}^{2+}$ increases in $\mathrm{B}$

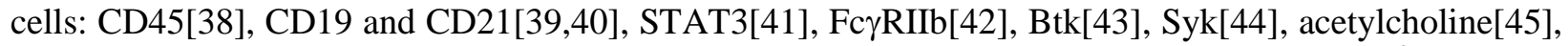
PCK [46], BLNK[47], Zap-70[48], c-Abl[49], c-Myc[50] and others. Non-voltage-gated $\mathrm{Ca}^{2+}$ channels with L-type characteristics can also be activated by BCR ligation[51]. Inhibitory phosphatases such as $\mathrm{CD} 22$ have also been shown to play a regulatory role in $\mathrm{Ca}^{2+}$ signaling, as BCR-triggered influx is enhanced in CD22-deficient B cells[52]. In addition, a number of BCR-specific features of $\mathrm{Ca}^{2+}$ signaling have been recently described with mechanisms involving signal amplification through CD20/CD81, PLC $\gamma 2 / I P 3 R / S T I M 1 / C R A C$, and BCR/cADPR/RYR3/CRAC pathways, as well as modulation pathways that involve CD22, Fc $\gamma$ RIIb, SHIP, and SHP1/2 (reviewed in Feske[53]).

Many other aspects of $\mathrm{Ca}^{2+}$ signaling in $\mathrm{B}$ cells have also been characterized. It was demonstrated that nonselective cation channels may be involved in BCR-independent $\mathrm{Ca}^{2+}$ increases in $\mathrm{B}$ cells due to shear stress[54] and hypotonicity[43,55,56]. Certain SOC properties of B-cell $\mathrm{Ca}^{2+}$ influx in response to BCRindependent stimulation with thapsigargin were also demonstrated[57]. In addition, other BCRindependent stimuli such as oxidant stress[43,58] and peroxide[38] have been shown to elevate intracellular $\mathrm{Ca}^{2+}$ in $\mathrm{B}$ cells. Lipid raft disruption was found to enhance the release of $\mathrm{Ca}^{2+}$ from intracellular stores, suggesting that rafts may sequester early signaling events that down-regulate $\mathrm{Ca}^{2+}$ influx[59]. Syk and Lyn also play a role in BCR-independent $\mathrm{Ca}^{2+}$-induced apoptosis in $\mathrm{B}$ cells after 


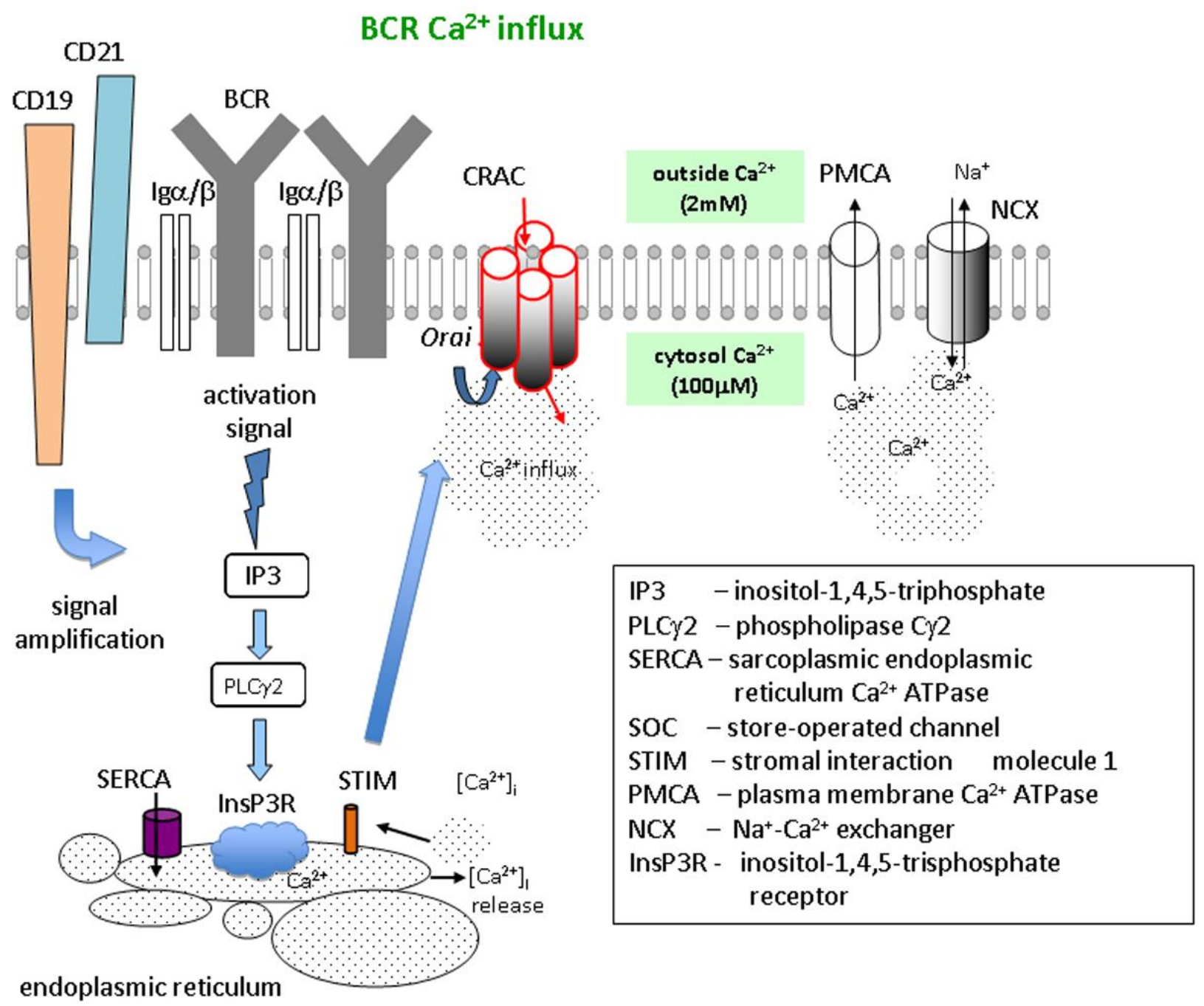

FIGURE 1. BCR-mediated $\mathrm{Ca}^{2+}$ influx. Upon ligation/cross-linking with an antigen, the BCR signaling complex (IgM/Ig $\alpha / \operatorname{Ig} \beta / C D 21 / C D 19)$ elicits an activation signal mediated by IP3, PLC $\gamma 2$, and InsP3R, leading to rapid depletion of $\mathrm{ER} \mathrm{Ca}^{2+}$ stores. $\mathrm{Ca}^{2+}$ released from the stores activates a specific type of transmembrane $\mathrm{Ca}^{2+}$ channel (CRAC) via STIM/Orai coupling and initiates $\mathrm{Ca}^{2+}$ influx from the extracellular environment. PMCA and NCX represent additional regulatory mechanisms for $\mathrm{Ca}^{2+}$ homeostasis.

treatment with nonselective $\mathrm{Ca}^{2+}$ ionophores[55]. BCR-dependent $\mathrm{Ca}^{2+}$ influx through DAG-activated $\mathrm{Ca}^{2+}$ entry channels was recently reported, and this mechanism involved TRPC 3 as both a $\mathrm{Ca}^{2+}$-permeable channel and a protein scaffold at the plasma membrane for downstream protein kinase $\mathrm{C} \beta$ (PKC $\beta$ ) activation in B cells. In anti-insulin, specific B-cell BCRs that are occupied by autologous insulin were shown to deliver signals that induce changes in intracellular $\mathrm{Ca}^{2+}$ mobilization and maintain tolerance by preventing activation of key transcription factors such as NFAT (nuclear factor of activated T cells)[60].

Recent studies have also addressed the role of $\mathrm{Ca}^{2+}$ signaling in B-cell gene expression. It was demonstrated that cytoplasmic $\mathrm{Ca}^{2+}$ oscillations have pronounced effects on lymphocyte gene expression/transcription factor activation profiles[7,61], and that distinct activating or inhibitory signaling events resulting from BCR engagement trigger qualitatively different downstream nuclear signals[62]. In particular, transient $\mathrm{Ca}^{2+}$ fluctuations appeared to regulate the translocation of nuclear factor $\kappa \mathrm{B}(\mathrm{NF}-\kappa \mathrm{B})$ into the nucleus, while continuous $\mathrm{Ca}^{2+}$ increases stimulated the recruitment of NFAT through different 
molecular mechanisms. The NF- $\mathrm{BB}$-mediated mechanism is well characterized in $\mathrm{B}$ cells and involves phospholipase $\mathrm{C} \gamma 2$ (PLC $\gamma 2$ ) and Bruton's tyrosine kinase (Btk) as intermediaries[63,64,65]. The activation of the NFAT pathway was shown to involve PKC $\delta$ and Ras GTPases[66]. Myc transcription factors were also implicated in B-lymphocyte proliferation and differentiation through the amplification of $\mathrm{Ca}^{2+}$ signals concurrent with the expression of Myc- and $\mathrm{Ca}^{2+}$-regulated target genes[67]. Notably, the exploration of the NFAT signaling pathway in lymphocytes with genome-wide single nucleotide polymorphism (SNP) mapping and RNAi screening led to the identification of Orail as a pore subunit of the CRAC channel[68].

However, despite many informative studies, the nature of $\mathrm{Ca}^{2+}$ signaling in mammalian $\mathrm{B}$ cells following BCR ligation and the mechanism of influx have not been characterized to the same extent as in T cells.

\section{SOURCE OF $\mathrm{Ca}^{2+}$ INVOLVED IN PROTEIN PHOSPHORYLATION EVENTS AND THE ROLE OF STORE-OPERATED INFLUX}

Antigen receptor-induced phosphorylation of protein kinases and phosphatases is required for activation of the BCR-mediated $\mathrm{Ca}^{2+}$ signaling pathway. In the absence of kinase phosphorylation, molecular pathways linking BCR ligation/activation to IP3 production are not functional because the phosphorylation and activation of PLC $\gamma$, which results in IP3 production, does not occur (reviewed in (Kurosaki[69]). In general, phosphotyrosine (pTyr) activity in lymphocytes is thought to precede the increase in intracellular $\mathrm{Ca}^{2+}$ concentration $[8,55,70,71,72]$ resulting from influx through SOC triggered by the release of relatively small quantities of $\mathrm{Ca}^{2+}$ from intracellular stores. However, the source of $\mathrm{Ca}^{2+}$ involved in the initial signaling protein phosphorylation is not well defined. It has been demonstrated that many initial BCR-triggered $\mathrm{Ca}^{2+}-$ dependent Tyr phosphorylation events involve primarily $\mathrm{Ca}^{2+}$ released from intracellular stores and do not depend on the extracellular influx[13]. This suggests a different role for this phase of $\mathrm{Ca}^{2+}$ influx. However, specific signaling molecules that become phosphorylated distinctly before or after the initiation of transmembrane $\mathrm{Ca}^{2+}$ influx are yet to be identified with a large-scale phosphoprotein array analysis. Other studies[73] have confirmed the interdependence between $\mathrm{Ca}^{2+}$ signaling and protein phosphorylation, in particular that the $\mathrm{Ca}^{2+}$ and reactive oxygen intermediates generated upon BCR activation can engage in a cooperative interaction that amplifies early signaling events.

The presence of two distinct types of $\mathrm{Ca}^{2+}$-mediated protein phosphorylation events (those that utilize $\mathrm{Ca}^{2+}$ released from intracellular stores and events relying on $\mathrm{Ca}^{2+}$ brought in by the transmembrane influx) raises a possibility for the following previously unanticipated regulatory role of $\mathrm{Ca}^{2+}$ in $\mathrm{B}$-cell activation. Initial $\mathrm{Ca}^{2+}$ increases resulting from the depletion of intracellular stores typically are significantly lower ( $\sim 10$-fold) than those caused by the transmembrane influx. It is possible that the low store-derived $\mathrm{Ca}^{2+}$ levels primarily accompany only the initial signaling events that are involved in cell activation, while the significantly higher postinflux $\mathrm{Ca}^{2+}$ levels that occur later may play an additional role in the inhibitory signaling cascades that down-regulate BCR activation.

\section{$\mathrm{Ca}^{2+}$ SIGNALING IN THE IMMUNE SYNAPSE AND MULTIFACETED $\mathrm{Ca}^{2+}$ RESPONSES WITHIN A SINGLE CELL}

The immune synapse is an important regulatory structure in B cells that transiently forms on the cell membrane during antigen processing and plays a key role in antigen presentation, interactions between different cells of the immune system, determining signaling thresholds through the engagement of coreceptors, and regulating localized increases of antigen density on the cell surface. Recent advances in the characterization of molecular mechanisms of immune synapse signaling are reviewed in Harwood and Batista[74]. 
Studies of the relationship between $\mathrm{Ca}^{2+}$ signaling and immune synapse dynamics demonstrated that $\mathrm{Ca}^{2+}$ signaling peak precedes the formation of central Super Molecular Activation Cluster (cSMAC) by estimated $300 \mathrm{sec}[13]$. This is consistent with other reports that found the immune synapse playing a down-regulatory role in NK and T-lymphocyte activation after the initial receptor engagement[75,76].

Recent reports have validated an important regulatory role of highly localized signaling events occurring within subcellular structures (microclusters) $[77,78,79]$. The role of $\mathrm{Ca}^{2+}$ in these processes in $\mathrm{B}$ cells during antigen response has not been fully investigated. Results published by our group[13] have revealed distinct synapse-related cytoplasmic $\mathrm{Ca}^{2+}$ gradients: $\mathrm{Ca}^{2+}$ levels in areas adjacent to the immune synapse were different from those in the rest of the cytoplasm, indicating that membrane $\mathrm{Ca}^{2+}$ channels in $\mathrm{B}$ cells may preferentially relocate (or be more active without relocation) to the area of the cell contacting a corpuscular/directional stimulus. Furthermore, in B cells that were forming multiple synapses (processing several antigen particles simultaneously), localized synaptic $\mathrm{Ca}^{2+}$ levels were also different probably due to different stages of signaling in the immune synapse areas. It is our interpretation that at later stages of synaptic signaling, the localized cytoplasmic $\mathrm{Ca}^{2+}$ levels were lower because the signaling complex has already assembled and $\mathrm{Ca}^{2+}$-dependent signaling initiation events have been completed; in contrast, at the early stages of cell/antigen interaction, $\mathrm{Ca}^{2+}$ levels are high in the area adjacent to the contact site (Fig. 2). Other reports also suggested that distinct areas within the SMAC (central part or cSMAC) act as a platform for immunoreceptor internalization and signaling termination[80].

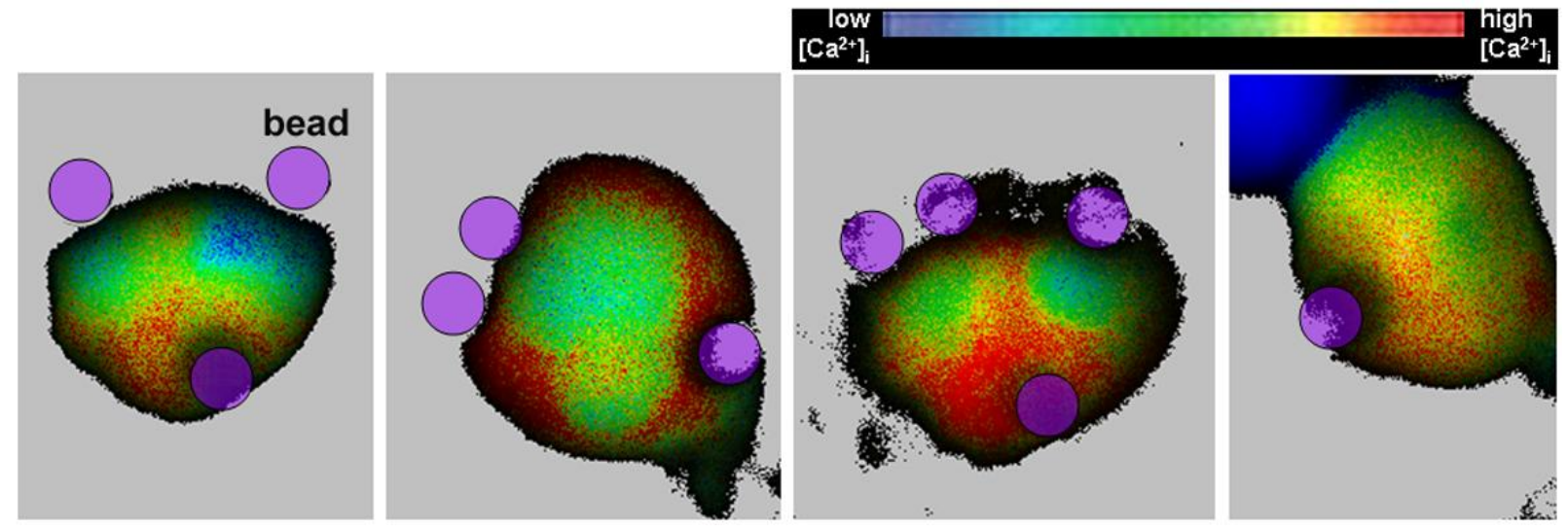

FIGURE 2. Heterogeneities in cytosol $\mathrm{Ca}^{2+}$ in $\mathrm{B}$ cells activated by anti-IgM-coated beads[13]. Examples of cytoplasmic $\mathrm{Ca}^{2+}$ gradients in murine $\mathrm{K} 46 \mu \mathrm{B}$ cells responding to a polarized stimulus. In these experiments, anti-IgM-coated beads (outlined in purple) were brought into contact with K46 $\mu$ cells labeled with intracellular $\mathrm{Ca}^{2+}$ probe Fura-2AM and adhered to the bottom of microscopic dish. Static images $(\lambda 340 / 380 \mathrm{~nm}$ ratio; random time points $<20 \mathrm{~min}$ ) demonstrate distinct high- and low-Ca ${ }^{2+}$ areas within the cytoplasm, reflecting different stages of signaling in the immune synapse area (beads were contacting B cells at random, thus interaction times were different). Each panel shows a single cell (40× magnification; cells are approximately $30 \mu \mathrm{m}$ in diameter).

These observations suggest the presence of a highly localized mechanism that enables compartmentalized regulation of $\mathrm{Ca}^{2+}$ levels within the cytoplasm and, as a result, a cell is able to process several corpuscular antigenic stimuli simultaneously and independently. This mechanism may have important implications for "multifaceted" responses, whereby a B cell that is not terminally differentiated is able to balance multiple stimuli of different antigen affinities/avidities and eventually select a "preferred" stimulus to develop a specific response against (based on BCR signal strength and timing, contributions from other signaling pathways through the involvement of coreceptors and other factors). A possible caveat to these conclusions is that intracellular $\mathrm{Ca}^{2+}$ gradients may appear as an imaging artifact due to intracellular granules having $\mathrm{Ca}^{2+}$ levels different from those in the bulk cytosol, as was described 
in cytotoxic T lymphocytes rich with acidic lytic granules[81]. However, B cells are not likely to contain nearly as much acidic granules as cytotoxic $\mathrm{T}$ cells. Furthermore, imaging artifacts that may appear as intracellular $\mathrm{Ca}^{2+}$ gradients due to different $\mathrm{Ca}^{2+}$ levels in the nucleus, intracellular granules, or other organelles ought to be distributed randomly (i.e., without any relation to the immune synapse site), which was not the case in the experiments shown in Fig. 2. Noteworthy, studies performed in cytotoxic T-cell lines demonstrated that $\mathrm{Ca}^{2+}$ channels do not cluster in the synapse area and are distributed uniformly throughout the cell surface during the first few seconds of signaling[81]. These data, however, were collected at much later time points (minutes into the synapse formation), which may account for the differences in results.

The presence of dynamic high- and low- $\mathrm{Ca}^{2+}$ areas within the immune synapse as well as larger-scale differences in $\mathrm{Ca}^{2+}$ dynamics in bulk cytosol vs. synapse area in a $\mathrm{B}$ cell responding to a localized antigen stimulus are likely indicative of highly localized $\mathrm{Ca}^{2+}$-dependent signaling events taking place in subcellular microclusters. One potential experimental approach to further investigate these findings would rely on the development of calmodulin/FRET-based $\mathrm{Ca}^{2+}$ sensors[79] targeted at molecules that participate in the formation of the immune synapse in B cells (Ig $\alpha / \beta, C D 19, C D 21)$. Such moleculetargeted biosensors can be used for real-time monitoring of $\mathrm{Ca}^{2+}$-dependent signaling events in the immediate proximity of molecular signaling microsites. In addition, the heterogeneities in BCR-triggered subcellular $\mathrm{Ca}^{2+}$ levels are likely to correlate with localized $\mathrm{Ca}^{2+}$-dependent $\mathrm{Tyr}$ phosphorylation events.

\section{ROLE OF CORECEPTORS IN BCR $\mathrm{Ca}^{2+}$ SIGNALING}

In addition to $\operatorname{IgM}$ and adjacent Ig $\alpha / \beta$ molecules, the BCR signaling complex engages many additional regulatory coreceptors, such as CD19, CD21, CD22, CD81[82,83]. One major innate immunity factor known to influence B-cell responses is complement, particularly the $\mathrm{C} 3 \mathrm{dg}$ protein, which is one of the cleavage products of the $\mathrm{C} 3$ component. Invasive pathogenic organisms spontaneously bind and fix complement. C3dg is a ligand for Complement Receptor 2 (CR2, also known as CD21) on the B-cell surface, and CR2-C3dg interaction greatly amplifies signals elicited by the binding of C3dg-attached antigen with its specific B-cell receptor (BCR)[40,82,84]. The complement-mediated signaling pathway can overcome the intracellular inhibitory mechanism responsible for maintaining clonal anergy in B cells. Spontaneous Ab-independent complement deposition on self-tissues and mimetic bacterial pathogens may be an important factor that can disrupt the regulatory mechanism responsible for keeping the potentially harmful autoreactive B cells from responding to self-antigens. One important characteristic of this mechanism is that, unlike BCR ligation with an $\mathrm{Ag}$ alone, a BCR/CR2-mediated response involves significantly lower (up to 1000-fold) doses of antigen and does not activate negative signal regulators, such as SHIP-1, SHP-1, SHP-2, and CD22, in order to elicit a comparable response[40]. This contributes to sustained complement-mediated B-cell activation due to lesser impact of signal inhibitors.

A number of studies focused on $\mathrm{Ca}^{2+}$ transport and signaling in $\mathrm{B}$ cells, and placed a special emphasis on the PLC $\gamma 2-I P 3-$ mediated mechanism of BCR and its coreceptor (CD19, CD21) $\mathrm{Ca}^{2+}$ signaling, as well as novel mechanisms for the regulation of cytosolic $\mathrm{Ca}^{2+}$ concentration. It has been discussed how these combined inputs could have an impact on the $\mathrm{Ca}^{2+}$-dependent regulation of NFAT and NF- $\mathrm{kB}$ transcription factor pathways, and influence cell-fate choice during humoral immune responses (reviewed in Scharenberg et al.[85]). Different B-cell subsets may differentially modulate $\mathrm{Ca}^{2+}$ signaling to control $\mathrm{B}$-cell fate and our previous findings demonstrated substantial differences in $\mathrm{Ca}^{2+}$ responses triggered by the engagement BCR[40] as well as BCR coreceptors, such as CD21[86], in B-cell subsets (mature, immature, marginal zone, B-1/B-2 cells) and effects on B-cell development. Recent reports[87] have also indicated that $\mathrm{CD} 21$-enhanced $\mathrm{Ca}^{2+}$ signaling plays a major role in overcoming $\mathrm{B}$-cell anergy and triggering antigen-specific $\mathrm{Ab}$ responses in a subset of anergic $\mathrm{B}$ cells. 


\section{$\mathrm{Ca}^{2+}$ SIGNALING AND MAINTENANCE OF B-CELL TOLERANCE AND CLINICAL SIGNIFICANCE OF B-CELL $\mathrm{Ca}^{2+}$ SIGNALING}

Alterations in $\mathrm{Ca}^{2+}$ signaling are recognized as one of the factors contributing to the loss of immune tolerance and anergy in B cells. Tolerized/anergic B cells have elevated baseline $\mathrm{Ca}^{2+}$ levels and sharply reduced response to BCR ligation[87,88], and this effect is not due to inactivation of STIM1[89]. Current consensus is that the high baseline intracellular $\mathrm{Ca}^{2+}$ concentration, which is characteristic of many experimental models of B-cell anergy, is due to the constant signals induced by the self-antigen binding[90], although it is not the case for some transgenic models[88]. Naïve B cells undergoing their initial response to antigen exhibit a rapid rise in intracellular $\mathrm{Ca}^{2+}$, but within a few minutes, levels fall to a plateau, which is maintained as long as antigen is present. This plateau level is equivalent to the high baseline of anergic cells. Thus, anergic cells are the physiologic equivalent of chronically antigenstimulated naïve cells.

Modulating BCR-mediated $\mathrm{Ca}^{2+}$ signaling mechanisms is a promising approach to treatment of $\mathrm{B}$ cell-related immune disorders. For example, it was shown that 1,4-benzodiazepine Bz-423 extends the rise in intracellular $\mathrm{Ca}^{2+}$ that accompanies anti-IgM stimulation, and this effect mediates the synergistic death response. Because hyperactivation and altered $\mathrm{Ca}^{2+}$ signaling are distinguishing features of autoreactive lymphocytes in autoimmune diseases such as lupus, Bz-423 is believed to preferentially target disease-causing cells for apoptosis on the basis of their activation state[91]. Also, $\mathrm{Ca}^{2+}$-activated neutral proteases (calpains) that become active in cells responding to signals inducing a rise of cytoplasmic $\mathrm{Ca}^{2+}$ are involved in the regulation of apoptosis of some cell types by interaction with caspase-3 and have been shown to play a role in B-cell survival[92].

Studies in human B cells that examined the role of extracellular $\mathrm{Ca}^{2+}$ sensing in promoting cell activation[93] have determined that responses to changes in extracellular $\mathrm{Ca}^{2+}$ levels activated PI3 kinase/AKT, calcineurin, ERK, p38 kinase, PKC, $\mathrm{Ca}^{2+} /$ calmodulin kinase II, and NF- $\mathrm{KB}$ signaling pathways, and resulted in transcription of the early response gene, $C D 83$. This extracellular $\mathrm{Ca}^{2+}$-sensing mechanism was also shown to enhance B-cell responses to TLR, BCR, and cytokine receptor agonists. These results may indicate a mechanism by which $\mathrm{B}$ cells prepare to engage in immune responses by responding to $\mathrm{Ca}^{2+}$ fluctuations in their environment.

Clinical aspects of $\mathrm{B}$-cell $\mathrm{Ca}^{2+}$ signaling are being investigated with increasing appreciation. For example, recently reported effects of Rituximab (anti-CD20 mAb) on BCR signaling revealed inhibition of the signaling cascade involving Lyn, Syk, PLC $\gamma 2$, Akt, and ERK, and $\mathrm{Ca}^{2+}$ mobilization. This inhibitory effect correlated with a decrease of raft-associated cholesterol, complete inhibition of BCR relocalization into lipid raft microdomains, and down-regulation of BCR immunoglobulin expression[94]. Impairment of $\mathrm{Ca}^{2+}$ signaling was shown to silence CD19 expression in primary pre-B cells by downregulating CD19 gene expression upon pre-BCR activation through inhibition of the E2A transcription factor by $\mathrm{Ca}^{2+} /$ calmodulin[95]. Another calmodulin-related protein, Pcp4, a molecule that modulates $\mathrm{Ca}^{2+}$ by binding to calmodulin via an IQ motif, was decreased in anergic and CD21-negative B cells[96,97,98]. BCR-mediated $\mathrm{Ca}^{2+}$ signaling was also impaired in $\mathrm{B}$ cells from patients with common variable immunodeficiency. Although in this instance proximal BCR signaling events were normal, including normal PLC $\gamma 2$ phosphorylation and $\mathrm{Ca}^{2+}$ release from intracellular stores, $\mathrm{Ca}^{2+}$ influx was significantly impaired. CD22, a negative regulator of $\mathrm{Ca}^{2+}$ signals in $\mathrm{B}$ cells, is highly expressed on $\mathrm{CD} 21_{\text {low }} \mathrm{B}$ cells in these patients and therefore might be involved in the attenuated $\mathrm{Ca}^{2+}$ response of this $\mathrm{B}$-cell subpopulation[99].

Overall, this mini-review tried to highlight several relatively underexplored aspects of $\mathrm{Ca}^{2+}$ signaling unique to B-lymphocyte responses to both antigen-specific and nonspecific stimuli. These areas are being actively studied to obtain further insights into the nature and molecular details of $\mathrm{Ca}^{2+}$ signaling in $\mathrm{B}$ lymphocytes. 


\section{REFERENCES}

1. Braun, J., Sha'afi, R.I., and Unanue, E.R. (1979) Crosslinking by ligands to surface immunoglobulin triggers mobilization of intracellular 45Ca2+ in B lymphocytes. J. Cell Biol. 82, 755-766.

2. Clevers, H.C., Bloem, A.C., Gmelig-Meyling, F., and Ballieux, R.E. (1985) Ligands of surface Ig raise cytoplasmic free $\mathrm{Ca}++$ in human B cells. Scand. J. Immunol. 22, 557-562.

3. LaBaer, J., Tsien, R.Y., Fahey, K.A., and DeFranco, A.L. (1986) Stimulation of the antigen receptor on WEHI-231 B lymphoma cells results in a voltage-independent increase in cytoplasmic calcium. J. Immunol. 137, 1836-1844.

4. Pozzan, T., Arslan, P., Tsien, R.Y., and Rink, T.J. (1982) Anti-immunoglobulin, cytoplasmic free calcium, and capping in B lymphocytes. J. Cell Biol. 94, 335-340.

5. $\quad$ Dugas, B., Calenda, A., Delfraissy, J.F., Vazquez, A., Bach, J.F., and Galanaud, P. (1987) The cytosolic free calcium in anti-mu-stimulated human B cells is derived partly from extracellular medium and partly from intracellular stores. Eur. J. Immunol. 17, 1323-1328.

6. Berridge, M.J., Lipp, P., and Bootman, M.D. (2000) The versatility and universality of calcium signalling. Nat. Rev. Mol. Cell Biol. 1, 11-21.

7. Dolmetsch, R.E., Lewis, R.S., Goodnow, C.C., and Healy, J.I. (1997) Differential activation of transcription factors induced by $\mathrm{Ca} 2+$ response amplitude and duration. Nature 386, 855-858.

8. Healy, J.I., Dolmetsch, R.E., Lewis, R.S., and Goodnow, C.C. (1998) Quantitative and qualitative control of antigen receptor signalling in tolerant B lymphocytes. Novartis Found. Symp. 215, 137-144; discussion 144-135, 186-190.

9. $\quad$ Luik, R.M., Wu, M.M., Buchanan, J., and Lewis, R.S. (2006) The elementary unit of store-operated Ca2+ entry: local activation of CRAC channels by STIM1 at ER-plasma membrane junctions. J. Cell Biol. 174, 815-825.

10. Peinelt, C., Vig, M., Koomoa, D.L., Beck, A., Nadler, M.J., Koblan-Huberson, M., Lis, A., Fleig, A., Penner, R., and Kinet, J.P. (2006) Amplification of CRAC current by STIM1 and CRACM1 (Orai1). Nat. Cell Biol. 8, 771-773.

11. Yeromin, A.V., Zhang, S.L., Jiang, W., Yu, Y., Safrina, O., and Cahalan, M.D. (2006) Molecular identification of the CRAC channel by altered ion selectivity in a mutant of Orai. Nature 443, 226-229.

12. Prakriya, M. and Lewis, R.S. (2003) CRAC channels: activation, permeation, and the search for a molecular identity. Cell Calcium 33, 311-321.

13. Lyubchenko, T., Nielsen, J.P., Miller, S.M., Liubchenko, G.A., and Holers, V.M. (2009) Role of initial protein phosphorylation events and localized release-activated calcium influx in B cell antigen receptor signaling. J. Leukoc. Biol. 85, 298-309.

14. Wu, M.M., Buchanan, J., Luik, R.M., and Lewis, R.S. (2006) Ca2+ store depletion causes STIM1 to accumulate in ER regions closely associated with the plasma membrane. J. Cell Biol. 174, 803-813.

15. Manji, S.S., Parker, N.J., Williams, R.T., van Stekelenburg, L., Pearson, R.B., Dziadek, M., and Smith, P.J. (2000) STIM1: a novel phosphoprotein located at the cell surface. Biochim. Biophys. Acta 1481, 147-155.

16. Oritani, K. and Kincade, P.W. (1996) Identification of stromal cell products that interact with pre-B cells. J. Cell Biol. 134, 771-782.

17. Engelke, M., Engels, N., Dittmann, K., Stork, B., and Wienands, J. (2007) Ca(2+) signaling in antigen receptoractivated B lymphocytes. Immunol. Rev. 218, 235-246.

18. Baba, Y., Hayashi, K., Fujii, Y., Mizushima, A., Watarai, H., Wakamori, M., Numaga, T., Mori, Y., Iino, M., Hikida, M., et al. (2006) Coupling of STIM1 to store-operated Ca2+ entry through its constitutive and inducible movement in the endoplasmic reticulum. Proc. Natl. Acad. Sci. U. S. A. 103, 16704-16709.

19. Chung, S.C., Limnander, A., Kurosaki, T., Weiss, A., and Korenbrot, J.I. (2007) Coupling Ca2+ store release to Icrac channel activation in B lymphocytes requires the activity of Lyn and Syk kinases. J. Cell Biol. 177, 317-328.

20. Smyth, J.T., Dehaven, W.I., Bird, G.S., and Putney, J.W., Jr. (2008) Ca2+-store-dependent and -independent reversal of Stim1 localization and function. J. Cell Sci. 121, 762-772.

21. Wissenbach, U., Philipp, S.E., Gross, S.A., Cavalie, A., and Flockerzi, V. (2007) Primary structure, chromosomal localization and expression in immune cells of the murine ORAI and STIM genes. Cell Calcium 42, 439-446.

22. Oh-Hora, M., Yamashita, M., Hogan, P.G., Sharma, S., Lamperti, E., Chung, W., Prakriya, M., Feske, S., and Rao, A. (2008) Dual functions for the endoplasmic reticulum calcium sensors STIM1 and STIM2 in T cell activation and tolerance. Nat. Immunol. 9, 432-443.

23. Strehler, E.E. and Treiman, M. (2004) Calcium pumps of plasma membrane and cell interior. Curr. Mol. Med. 4, 323335 .

24. Bautista, D.M. and Lewis, R.S. (2004) Modulation of plasma membrane calcium-ATPase activity by local calcium microdomains near CRAC channels in human T cells. J. Physiol. 556, 805-817. Guerini, D., Coletto, L., and Carafoli, E. (2005) Exporting calcium from cells. Cell Calcium 38, 281-289.

26. Jacobson, J. and Duchen, M.R. (2004) Interplay between mitochondria and cellular calcium signalling. Mol. Cell. Biochem. 256-257, 209-218.

27. Patterson, R.L., Boehning, D., and Snyder, S.H. (2004) Inositol 1,4,5-trisphosphate receptors as signal integrators. Annu. Rev. Biochem. 73, 437-465.

28. Parekh, A.B. and Penner, R. (1997) Store depletion and calcium influx. Physiol. Rev. 77, 901-930

29. Cahalan, M.D., Wulff, H., and Chandy, K.G. (2001) Molecular properties and physiological roles of ion channels in the immune system. J. Clin. Immunol. 21, 235-252. 
30. Panyi, G. (2005) Biophysical and pharmacological aspects of K+ channels in T lymphocytes. Eur. Biophys. J. 34, $515-529$.

31. Launay, P., Fleig, A., Perraud, A.L., Scharenberg, A.M., Penner, R., and Kinet, J.P. (2002) TRPM4 is a Ca2+activated nonselective cation channel mediating cell membrane depolarization. Cell 109, 397-407.

32. Prawitt, D., Monteilh-Zoller, M.K., Brixel, L., Spangenberg, C., Zabel, B., Fleig, A., and Penner, R. (2003) TRPM5 is a transient $\mathrm{Ca} 2+$-activated cation channel responding to rapid changes in $[\mathrm{Ca} 2+]$ i. Proc. Natl. Acad. Sci. U. S. A. 100, $15166-15171$.

33. Basu, S. and Srivastava, P. (2005) Immunological role of neuronal receptor vanilloid receptor 1 expressed on dendritic cells. Proc. Natl. Acad. Sci. U. S. A. 102, 5120-5125.

34. Mori, Y., Wakamori, M., Miyakawa, T., Hermosura, M., Hara, Y., Nishida, M., Hirose, K., Mizushima, A., Kurosaki, M., Mori, E., et al. (2002) Transient receptor potential 1 regulates capacitative $\mathrm{Ca}(2+)$ entry and $\mathrm{Ca}(2+)$ release from endoplasmic reticulum in B lymphocytes. J. Exp. Med. 195, 673-681.

35. Putney, J.W., Jr., Broad, L.M., Braun, F.J., Lievremont, J.P., and Bird, G.S. (2001) Mechanisms of capacitative calcium entry. J. Cell Sci. 114, 2223-2229.

36. Hogan, P.G., Lewis, R.S., and Rao, A. (2010) Molecular basis of calcium signaling in lymphocytes: STIM and ORAI. Annu. Rev. Immunol. 28, 491-533.

37. King, L.B. and Freedman, B.D. (2009) B-lymphocyte calcium influx. Immunol. Rev. 231, 265-277.

38. Qin, S. and Chock, P.B. (2002) Tyrosine phosphatase CD45 regulates hydrogen peroxide-induced calcium mobilization in B cells. Antioxid. Redox Signal. 4, 481-490.

39. Buhl, A.M., Pleiman, C.M., Rickert, R.C., and Cambier, J.C. (1997) Qualitative regulation of B cell antigen receptor signaling by CD19: selective requirement for PI3-kinase activation, inositol-1,4,5-trisphosphate production and Ca2+ mobilization. J. Exp. Med. 186, 1897-1910.

40. Lyubchenko, T., dal Porto, J., Cambier, J.C., and Holers, V.M. (2005) Coligation of the B cell receptor with complement receptor type 2 (CR2/CD21) using its natural ligand C3dg: activation without engagement of an inhibitory signaling pathway. J. Immunol. 174, 3264-3272.

41. Fan, H. and Rothstein, T.L. (2001) Lymphokine dependence of STAT3 activation produced by surface immunoglobulin cross-linking and by phorbol ester plus calcium ionophore treatment in B cells. Eur. J. Immunol. 31, 665-671.

42. Enyedy, E.J., Mitchell, J.P., Nambiar, M.P., and Tsokos, G.C. (2001) Defective FcgammaRIIb1 signaling contributes to enhanced calcium response in B cells from patients with systemic lupus erythematosus. Clin. Immunol. 101, 130135.

43. Qin, S., Stadtman, E.R., and Chock, P.B. (2000) Regulation of oxidative stress-induced calcium release by phosphatidylinositol 3-kinase and Bruton's tyrosine kinase in B cells. Proc. Natl. Acad. Sci. U. S. A. 97, 7118-7123.

44. Kulathu, Y., Hobeika, E., Turchinovich, G., and Reth, M. (2008) The kinase Syk as an adaptor controlling sustained calcium signalling and B-cell development. EMBO J. 27, 1333-1344.

45. Fujii, T. and Kawashima, K. (2000) Calcium signaling and c-Fos gene expression via M3 muscarinic acetylcholine receptors in human T- and B-cells. Jpn. J. Pharmacol. 84, 124-132.

46. Pracht, C., Minguet, S., Leitges, M., Reth, M., and Huber, M. (2007) Association of protein kinase C-delta with the B cell antigen receptor complex. Cell. Signal. 19, 715-722.

47. Wollscheid, B., Wienands, J., and Reth, M. (1999) The adaptor protein SLP-65/BLNK controls the calcium response in activated B cells. Curr. Top. Microbiol. Immunol. 246, 283-288; discussion 288-289.

48. Schweighoffer, E., Vanes, L., Mathiot, A., Nakamura, T., and Tybulewicz, V.L. (2003) Unexpected requirement for ZAP-70 in pre-B cell development and allelic exclusion. Immunity 18, 523-533.

49. Liberatore, R.A. and Goff, S.P. (2009) c-Abl-deficient mice exhibit reduced numbers of peritoneal B-1 cells and defects in BCR-induced B cell activation. Int. Immunol. 21, 403-414.

50. Donjerkovic, D., Zhang, L., and Scott, D.W. (1999) Regulation of p27Kip1 accumulation in murine B-lymphoma cells: role of c-Myc and calcium. Cell Growth Differ. 10, 695-704.

51. Grafton, G., Stokes, L., Toellner, K.M., and Gordon, J. (2003) A non-voltage-gated calcium channel with L-type characteristics activated by B cell receptor ligation. Biochem. Pharmacol. 66, 2001-2009.

52. Nadler, M.J., McLean, P.A., Neel, B.G., and Wortis, H.H. (1997) B cell antigen receptor-evoked calcium influx is enhanced in CD22-deficient B cell lines. J. Immunol. 159, 4233-4243.

53. Feske, S. (2007) Calcium signalling in lymphocyte activation and disease. Nat. Rev. 7, 690-702.

54. Liu, Q.H., Liu, X., Wen, Z., Hondowicz, B., King, L., Monroe, J., and Freedman, B.D. (2005) Distinct calcium channels regulate responses of primary B lymphocytes to B cell receptor engagement and mechanical stimuli. $J$. Immunol. 174, 68-79.

55. Zhu, D.M., Tibbles, H.E., Vassilev, A.O., and Uckun, F.M. (2002) SYK and LYN mediate B-cell receptorindependent calcium-induced apoptosis in DT-40 lymphoma B-cells. Leuk. Lymphoma 43, 2165-2170.

56. Zhu, P., Liu, X., Labelle, E.F., and Freedman, B.D. (2005) Mechanisms of hypotonicity-induced calcium signaling and integrin activation by arachidonic acid-derived inflammatory mediators in B cells. J. Immunol. 175, 4981-4989.

57. Feske, S., Giltnane, J., Dolmetsch, R., Staudt, L.M., and Rao, A. (2001) Gene regulation mediated by calcium signals in T lymphocytes. Nat. Immunol. 2, 316-324. 
58. Qin, S., Inazu, T., Takata, M., Kurosaki, T., Homma, Y., and Yamamura, H. (1996) Cooperation of tyrosine kinases p72syk and p53/56lyn regulates calcium mobilization in chicken B cell oxidant stress signaling. Eur. J. Biochem. 236, 443-449.

59. Petrie, R.J., Schnetkamp, P.P., Patel, K.D., Awasthi-Kalia, M., and Deans, J.P. (2000) Transient translocation of the B cell receptor and Src homology 2 domain-containing inositol phosphatase to lipid rafts: evidence toward a role in calcium regulation. J. Immunol. 165, 1220-1227.

60. Acevedo-Suarez, C.A., Kilkenny, D.M., Reich, M.B., and Thomas, J.W. (2006) Impaired intracellular calcium mobilization and NFATc1 availability in tolerant anti-insulin B cells. J. Immunol. 177, 2234-2241.

61. Dolmetsch, R.E., Xu, K., and Lewis, R.S. (1998) Calcium oscillations increase the efficiency and specificity of gene expression. Nature 392, 933-936.

62. Healy, J.I., Dolmetsch, R.E., Timmerman, L.A., Cyster, J.G., Thomas, M.L., Crabtree, G.R., Lewis, R.S., and Goodnow, C.C. (1997) Different nuclear signals are activated by the B cell receptor during positive versus negative signaling. Immunity 6, 419-428.

63. Bajpai, U.D., Zhang, K., Teutsch, M., Sen, R., and Wortis, H.H. (2000) Bruton's tyrosine kinase links the B cell receptor to nuclear factor kappaB activation. J. Exp. Med. 191, 1735-1744.

64. Petro, J.B. and Khan, W.N. (2001) Phospholipase C-gamma 2 couples Bruton's tyrosine kinase to the NF-kappaB signaling pathway in B lymphocytes. J. Biol. Chem. 276, 1715-1719.

65. Petro, J.B., Rahman, S.M., Ballard, D.W., and Khan, W.N. (2000) Bruton's tyrosine kinase is required for activation of IkappaB kinase and nuclear factor kappaB in response to B cell receptor engagement. J. Exp. Med. 191, 17451754.

66. Antony, P., Petro, J.B., Carlesso, G., Shinners, N.P., Lowe, J., and Khan, W.N. (2003) B cell receptor directs the activation of NFAT and NF-kappaB via distinct molecular mechanisms. Exp. Cell Res. 291, 11-24.

67. Habib, T., Park, H., Tsang, M., de Alboran, I.M., Nicks, A., Wilson, L., Knoepfler, P.S., Andrews, S., Rawlings, D.J., Eisenman, R.N., et al. (2007) Myc stimulates B lymphocyte differentiation and amplifies calcium signaling. J. Cell Biol. 179, 717-731.

68. Gwack, Y., Feske, S., Srikanth, S., Hogan, P.G., and Rao, A. (2007) Signalling to transcription: store-operated Ca2+ entry and NFAT activation in lymphocytes. Cell Calcium 42, 145-156.

69. Kurosaki, T. (2000) Functional dissection of BCR signaling pathways. Curr. Opin. Immunol. 12, $276-281$.

70. Cambier, J.C., Pleiman, C.M., and Clark, M.R. (1994) Signal transduction by the B cell antigen receptor and its coreceptors. Annu. Rev. Immunol. 12, 457-486.

71. Lane, P.J., Ledbetter, J.A., McConnell, F.M., Draves, K., Deans, J., Schieven, G.L., and Clark, E.A. (1991) The role of tyrosine phosphorylation in signal transduction through surface Ig in human B cells. Inhibition of tyrosine phosphorylation prevents intracellular calcium release. J. Immunol. 146, 715-722.

72. Takata, M., Sabe, H., Hata, A., Inazu, T., Homma, Y., Nukada, T., Yamamura, H., and Kurosaki, T. (1994) Tyrosine kinases Lyn and Syk regulate B cell receptor-coupled Ca2+ mobilization through distinct pathways. EMBO J. 13, 1341-1349.

73. Singh, D.K., Kumar, D., Siddiqui, Z., Basu, S.K., Kumar, V., and Rao, K.V. (2005) The strength of receptor signaling is centrally controlled through a cooperative loop between $\mathrm{Ca} 2+$ and an oxidant signal. Cell 121, 281-293.

74. Harwood, N.E. and Batista, F.D. (2010) Early events in B cell activation. Annu. Rev. Immunol. 28, $185-210$.

75. Almeida, C.R. and Davis, D.M. (2006) Segregation of HLA-C from ICAM-1 at NK cell immune synapses is controlled by its cell surface density. J. Immunol. 177, 6904-6910.

76. Sumoza-Toledo, A., Eaton, A.D., and Sarukhan, A. (2006) Regulatory T cells inhibit protein kinase C theta recruitment to the immune synapse of naive T cells with the same antigen specificity. J. Immunol. 176, 5779-5787.

77. Altan-Bonnet, G. and Germain, R.N. (2005) Modeling T cell antigen discrimination based on feedback control of digital ERK responses. PLoS Biol. 3, e356.

78. Palmer, A.E., Jin, C., Reed, J.C., and Tsien, R.Y. (2004) Bcl-2-mediated alterations in endoplasmic reticulum Ca2+ analyzed with an improved genetically encoded fluorescent sensor. Proc. Natl. Acad. Sci. U. S. A. 101, 17404-17409.

79. Palmer, A.E. and Tsien, R.Y. (2006) Measuring calcium signaling using genetically targetable fluorescent indicators. Nat. Protoc. 1, 1057-1065.

80. Lee, K.H., Holdorf, A.D., Dustin, M.L., Chan, A.C., Allen, P.M., and Shaw, A.S. (2002) T cell receptor signaling precedes immunological synapse formation. Science 295, 1539-1542.

81. Lyubchenko, T.A., Wurth, G.A., and Zweifach, A. (2001) Role of calcium influx in cytotoxic T lymphocyte lytic granule exocytosis during target cell killing. Immunity 15, 847-859.

82. Fearon, D.T. and Carroll, M.C. (2000) Regulation of B lymphocyte responses to foreign and self-antigens by the CD19/CD21 complex. Annu. Rev. Immunol. 18, 393-422.

83. Poe, J.C., Hasegawa, M., and Tedder, T.F. (2001) CD19, CD21, and CD22: multifaceted response regulators of B lymphocyte signal transduction. Int. Rev. Immunol. 20, 739-762.

84. Henson, S.E., Smith, D., Boackle, S.A., Holers, V.M., and Karp, D.R. (2001) Generation of recombinant human C3dg tetramers for the analysis of CD21 binding and function. J. Immunol. Methods 258, 97-109.

85. Scharenberg, A.M., Humphries, L.A., and Rawlings, D.J. (2007) Calcium signalling and cell-fate choice in B cells. Nat. Rev. 7, 778-789. 
86. Kulik, L., Marchbank, K.J., Lyubchenko, T., Kuhn, K.A., Liubchenko, G.A., Haluszczak, C., Gipson, M.G., Boackle, S.A., and Holers, V.M. (2007) Intrinsic B cell hypo-responsiveness in mice prematurely expressing human CR2/CD21 during B cell development. Eur. J. Immunol. 37, 623-633.

87. Lyubchenko, T., Dal Porto, J.M., Holers, V.M., and Cambier, J.C. (2007) Cutting edge: complement (C3d)-linked antigens break B cell anergy. J. Immunol. 179, 2695-2699.

88. Cambier, J.C., Gauld, S.B., Merrell, K.T., and Vilen, B.J. (2007) B-cell anergy: from transgenic models to naturally occurring anergic B cells? Nat. Rev. Immunol. 7, 633-643.

89. Yarkoni, Y., Getahun, A., and Cambier, J.C. (2010) Molecular underpinning of B-cell anergy. Immunol. Rev. 237, 249-263.

90. Gauld, S.B., Benschop, R.J., Merrell, K.T., and Cambier, J.C. (2005) Maintenance of B cell anergy requires constant antigen receptor occupancy and signaling. Nat. Immunol. 6, 1160-1167.

91. Bednarski, J.J., Lyssiotis, C.A., Roush, R., Boitano, A.E., Glick, G.D., and Opipari, A.W., Jr. (2004) A novel benzodiazepine increases the sensitivity of B cells to receptor stimulation with synergistic effects on calcium signaling and apoptosis. J. Biol. Chem. 279, 29615-29621.

92. Witkowski, J.M., Zmuda-Trzebiatowska, E., Swiercz, J.M., Cichorek, M., Ciepluch, H., Lewandowski, K., Bryl, E., and Hellmann, A. (2002) Modulation of the activity of calcium-activated neutral proteases (calpains) in chronic lymphocytic leukemia (B-CLL) cells. Blood 100, 1802-1809.

93. Hammond, C.M., White, D., Tomic, J., Shi, Y., and Spaner, D.E. (2007) Extracellular calcium sensing promotes human B-cell activation and function. Blood 110, 3985-3995.

94. Kheirallah, S., Caron, P., Gross, E., Quillet-Mary, A., Bertrand-Michel, J., Fournie, J.J., Laurent, G., and Bezombes, C. (2010) Rituximab inhibits B-cell receptor signaling. Blood 115, 985-994.

95. Hauser, J., Wallenius, A., Sveshnikova, N., Saarikettu, J., and Grundstrom, T. (2010) Calmodulin inhibition of E2A stops expression of surrogate light chains of the pre-B-cell receptor and CD19. Mol. Immunol. 47, 1031-1038.

96. Glynne, R., Ghandour, G., Rayner, J., Mack, D.H., and Goodnow, C.C. (2000) B-lymphocyte quiescence, tolerance and activation as viewed by global gene expression profiling on microarrays. Immunol. Rev. 176, 216-246.

97. Isnardi, I., Ng, Y.S., Menard, L., Meyers, G., Saadoun, D., Srdanovic, I., Samuels, J., Berman, J., Buckner, J.H., Cunningham-Rundles, C., et al. (2010) Complement receptor 2/CD21- human naive B cells contain mostly autoreactive unresponsive clones. Blood 115, 5026-5036.

98. Jacobson, A.C., Weis, J.J., and Weis, J.H. (2009) CD21 signaling via C3 regulates Purkinje cell protein 4 expression. Mol. Immunol. 46, 1488-1493.

99. Foerster, C., Voelxen, N., Rakhmanov, M., Keller, B., Gutenberger, S., Goldacker, S., Thiel, J., Feske, S., Peter, H.H., and Warnatz, K. (2010) B cell receptor-mediated calcium signaling is impaired in B lymphocytes of type Ia patients with common variable immunodeficiency. J. Immunol. 184, 7305-7313.

\section{This article should be cited as follows:}

Lyubchenko, T. (2010) $\mathrm{Ca}^{2+}$ signaling in B cells. TheScientificWorldJOURNAL 10, 2254-2264. DOI 10.1100/tsw.2010.219. 

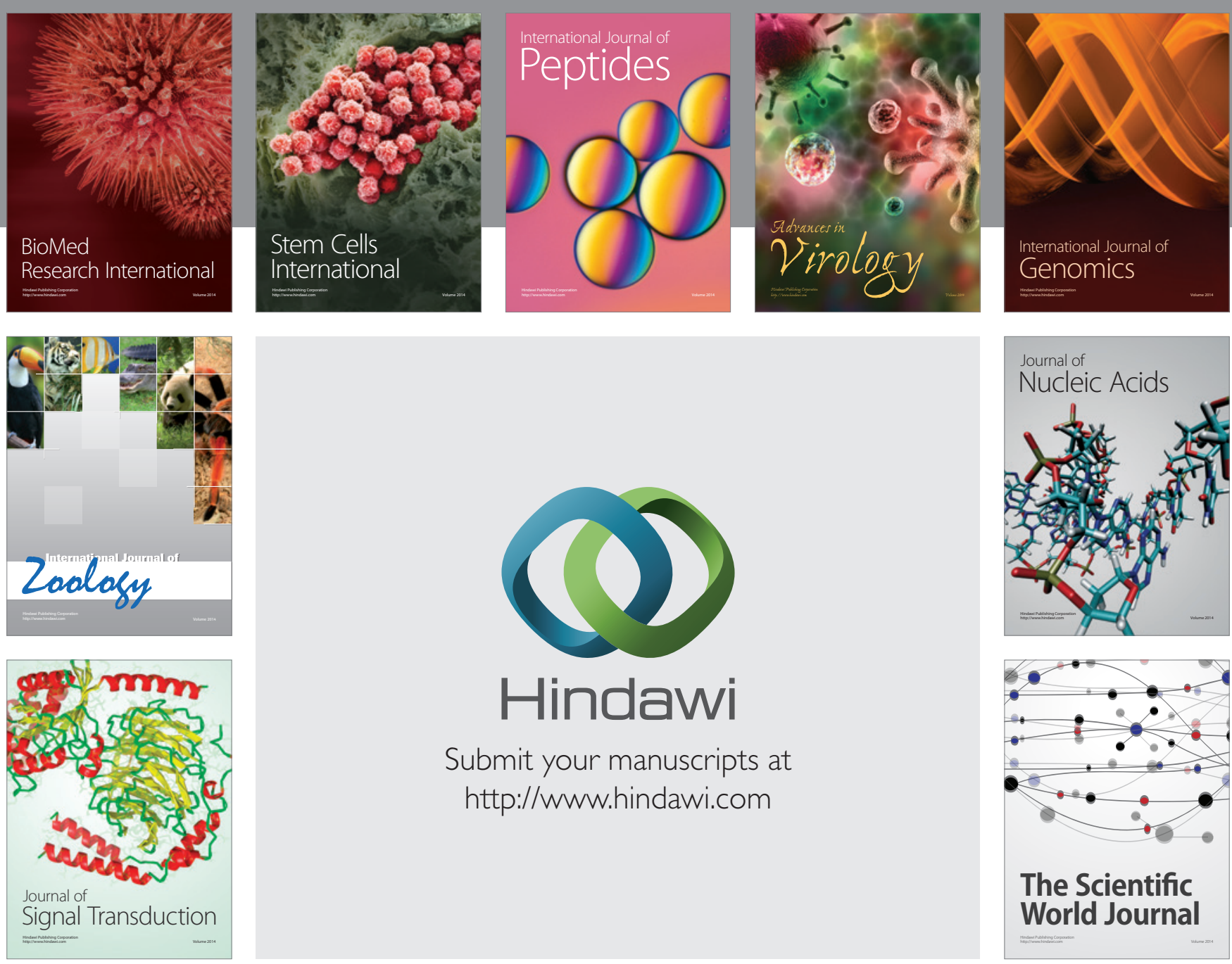

Submit your manuscripts at

http://www.hindawi.com
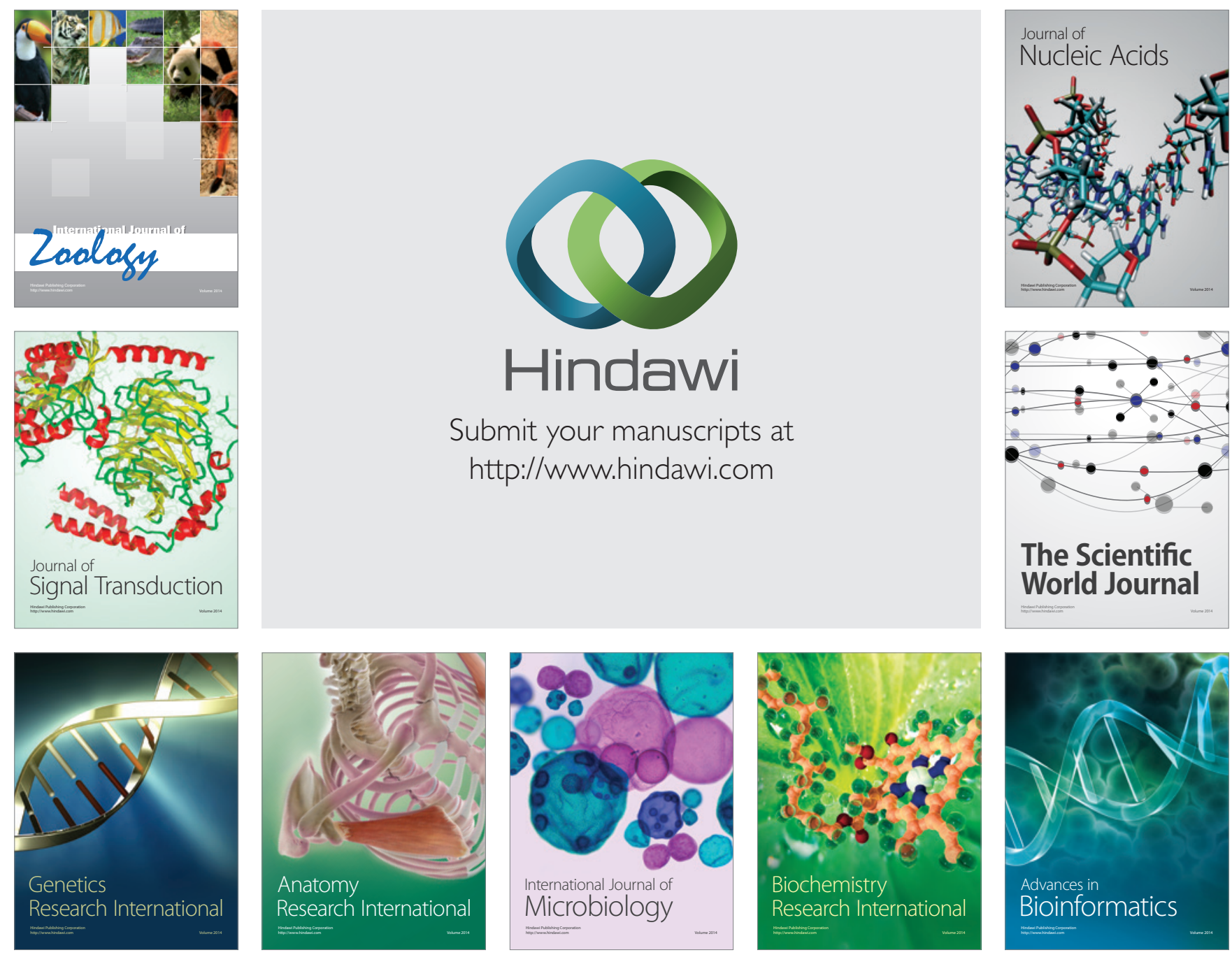

The Scientific World Journal
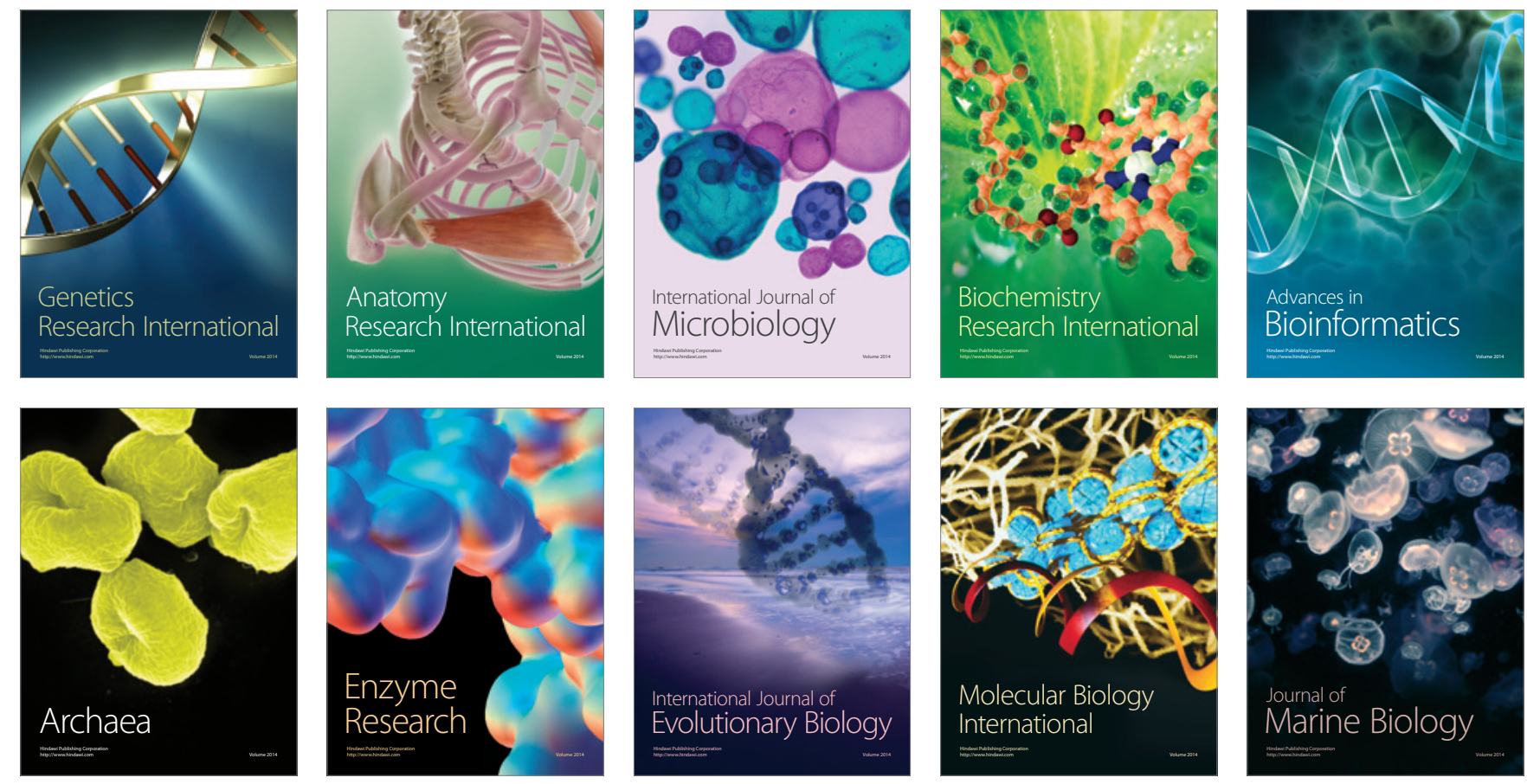